\title{
ГЕОЛОГО-ГЕОФИЗИЧЕСКИЕ КРИТЕРИИ ПРОГНОЗА КОЛЛЕКТОРОВ И НЕФТЕГАЗОНОСНОСТИ ДОЮРСКОГО ОСНОВАНИЯ
}

Нассонова Н.В., Коростелева Е.Ф., Руб̆лев М.Е., Светлакова Н.Ю. (OOO «ТННЦ»)

Для того чтобы выделить коллектора в доюрском основании необходим комплексный подход. Примененне такого метода позволило открыть залежь в доюрском основании на Копитьском месторожденни.

Что касается запада ХМАО, то хорошими дебитами характеризуется кора выветривания на Каменном месторождении, так называемая зона контакта осадочного чехла и доюрского основания.

Отложения фундамента - разновозрастные. Вещественный состав представлен карбонатными, терригенно-карбонатными, магматическими и метаморфическими породами. Коллектора в данњых отложениях сформировались в результате эндогенных и экзогенных процессов. Больпую роль в формировании резервуаров и экранов играют тектонические (разрывные, трещинные) дислокация. Общеизвестно, что наиболее сильно корообразованию были подвержены эрозионные выступы и палеоподнятия. Так, на Каменном месторождения из скв.40006 из приконтактной зоны с глубины около 100 м от этой зоны получен промышленный приток нефти, причем совместный приток составил $82,6 \mathrm{~m}^{3} /$ сут на 8 мм штуцере. Породы представлены в этой скважине трещиноватыми кварцитами. На западе XMAO имеется ряд признаков, по которым можно

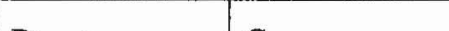

\begin{tabular}{|c|c|c|c|c|c|c|}
\hline $\begin{array}{l}\text { Региональ- } \\
\text { ные }\end{array}$ & $\begin{array}{l}\text { Структурно- } \\
\text { тектонические }\end{array}$ & $\begin{array}{l}\text { Сейсм- } \\
\text { геоло- } \\
\text { гиче- } \\
\text { ские и } \\
\text { потен- } \\
\text { цальные } \\
\text { поля }\end{array}$ & $\begin{array}{l}\text { Литолого- } \\
\text { стратитра- } \\
\text { фические }\end{array}$ & $\begin{array}{l}\text { Геохимче- } \\
\text { ские и гид- } \\
\text { рогеологи- } \\
\text { ческие }\end{array}$ & $\begin{array}{l}\text { Палео- } \\
\text { гео- } \\
\text { морфо- } \\
\text { логиче- } \\
\text { ские }\end{array}$ & $\begin{array}{l}\text { Прямыте } \\
\text { признаки }\end{array}$ \\
\hline $\begin{array}{l}\text { Наличе залежей } \\
\text { в осадочном } \\
\text { чехле }\end{array}$ & $\begin{array}{l}\text { Кровля коры } \\
\text { выветривания } \\
\text { до.жна быть } \\
\text { выпе водонефтя- } \\
\text { ных контактов } \\
\text { нижнеюрких или } \\
\text { любых приле- } \\
\text { гающих или обле- } \\
\text { гающих юрских } \\
\text { птастов }\end{array}$ & $\begin{array}{l}\text { Опреде- } \\
\text { ление зон } \\
\text { разуплот- } \\
\text { нения, } \\
\text { комплек- } \\
\text { сирование } \\
\text { гравики, } \\
\text { ГИС, } \\
\text { сейсиики. }\end{array}$ & $\begin{array}{l}\text { Предпочти- } \\
\text { тельный } \\
\text { веществен- } \\
\text { ный состав - } \\
\text { карбонат- } \\
\text { ный. }\end{array}$ & $\begin{array}{l}\text { Облекание и } \\
\text { прилегание к } \\
\text { выступам фун- } \\
\text { дамента пород } \\
\text { обладающцх } \\
\text { выским нефте- } \\
\text { материнским } \\
\text { потенциалом }\end{array}$ & $\begin{array}{l}\text { Натичие } \\
\text { инверсии } \\
\text { структур- } \\
\text { ного пла- } \\
\text { на }\end{array}$ & $\begin{array}{l}\text { Наличие } \\
\text { признаков } \\
\text { нефтена- } \\
\text { сыщения: } \\
\text { нефтяной } \\
\text { керн, при- } \\
\text { токи угле- } \\
\text { водородов. }\end{array}$ \\
\hline $\begin{array}{l}\text { Территория } \\
\text { располо-гается в } \\
\text { б.тизи крупных } \\
\text { впадин и грабен } \\
\text { рифтов }\end{array}$ & $\begin{array}{l}\text { Налнчие разломов } \\
\text { и зон трешинова- } \\
\text { тости }\end{array}$ & $\begin{array}{l}\text { Прогноз } \\
\text { по сейс- } \\
\text { мическим } \\
\text { данным, } \\
\text { расчет } \\
\text { пинамики } \\
\text { атрибу- } \\
\text { тов. }\end{array}$ & $\begin{array}{l}\text { Прогноз } \\
\text { веществен- } \\
\text { ного состава } \\
\text { по значени- } \\
\text { я гранич- } \\
\text { ных скоро- } \\
\text { стей }\end{array}$ & $\begin{array}{l}\text { Геохимия по- } \\
\text { род: потенциал } \\
\text { нефтематерин- } \\
\text { ских пород. }\end{array}$ & & \\
\hline $\begin{array}{l}\text { Наличие в дан- } \\
\text { ном регионе } \\
\text { «покрышек» над } \\
\text { доюрским осно- } \\
\text { ванием }\end{array}$ & $\begin{array}{l}\text { Натичие крупных } \\
\text { поднятий и вы- } \\
\text { ступов в фужда- } \\
\text { менте }\end{array}$ & $\begin{array}{l}\text { Нахожде- } \\
\text { ние мно- } \\
\text { гомерных } \\
\text { связей }\end{array}$ & $\begin{array}{l}\text { Наличие зон } \\
\text { метасомато- } \\
\text { за и гидро- } \\
\text { термальной } \\
\text { проработки }\end{array}$ & $\begin{array}{l}\text { Степень ката- } \\
\text { генеза и потен- } \\
\text { циал самого } \\
\text { доюрского } \\
\text { основания }\end{array}$ & & \\
\hline $\begin{array}{l}\text { Региональные и } \\
\text { стратитрафиче- } \\
\text { ские зоны пере- } \\
\text { рывов и несо- } \\
\text { г.асий }\end{array}$ & $\begin{array}{l}\text { Налнчие молодых } \\
\text { разломов. Нали- } \\
\text { чие разломов на } \\
\text { границах крупных } \\
\text { блоков фудамента }\end{array}$ & & & $\begin{array}{l}\text { Концентрация } \\
\text { растворенных } \\
\text { газов и редко- } \\
\text { земельных } \\
\text { элементов }\end{array}$ & & \\
\hline
\end{tabular}
прогнозировать ловушки и залежи углеводородов: наличие эрозионного унаследованного выступа отложения продуктивны там, где выклиниваются отложения тюменской свиты, то есть они максимально приближены к нефтематеринской породе (баженовской свите); наличие тектонических нарушений, прослеженных на временных разрезах; присутствие зффекта затухания и т.д.

Неменьший интерес вызывают данные отложения и на востоке XМАО. Так, на Кошильском месторождении в скв.204 из карбонатов палеозоя в

интервале 2802-2812 м получено $3,4 \mathrm{~m}^{3} /$ сут нефти при депрессии 6 мПа. В остальных 11 скважинах, вскрывших на данной плоцади фундамент, только в одной - скв.301 получен приток водонефтяной эмульсии дебитом $0,5 \mathrm{~m}^{3} /$ сут. Породы представлены на востоке Кошильской площади - карбонатами, на западе - скв.306, 204, 347, 3010 мергелями и глинисто-кремнистыми сланцами. Наличие сейсмики $3 Д$ на данной площади м методика прогноза коллекторов по спектральной декомпозиции позволили выявить мозаичное строение коллектора.

Предложена таблица комбинированных поисковых критериев по доюрскому основанию. 